\title{
ipexiscape.
}

\section{With the Assistance of the Following Collaborators:}

Chas.Lewis Allen, M.D.,Wash.,D.C.K. K. Macalester, M.D., N.Y. J.S. Christison, M.D., Chicago, Iil. J. K. Mitchell. M.D., Phila., Pa A. Freeman, M.D., New York. S. E. Jelififfe, M.D., New York.

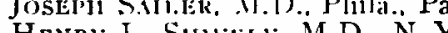
W. M. L.sziNsky, M.D., New York A. Sterne, M.D., Indianapolis.

\section{ANATOMY.}

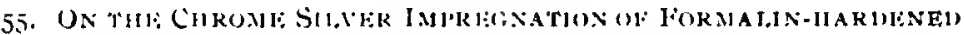
BraIN. J. S. Bolton (i ancet, i., 1808. 1). I28).

The author has obtained excellent (inlgi preparations from specimen- fixed in formalin, 5 per cent., for a period of from two to twelve mombs. His results were kess sittisfactory if the formalin hardening was les. thitll two weeks. Speciniens should be cut preferably oneeightl $v i$ an incli thick. After fixation the specimens are transferred to a bath of 1 per cenl. almmmmitmm hichromate, where they may remain for from a iew hours to five days. after which time the impregnation deteriorates the pictures obtained. Other chromic acid preparations gare less pronlising results. Aiter the proper time of innuersion in the lichromate the pieces are transferred, after rinsing in distilled water, into 1 per ecut. silver nitrate. where they remain from sixteen to twenty-four hours. A longer immersion in the silver did not hurt the impregnation. The specimens are then hardened in 60 per cent. alcoliol for a few hours, dried and imbedeled in melted paraffine without soaking and cut, cleared and mounted in balsam withnut cover slip.

JEI.I.1FFE.

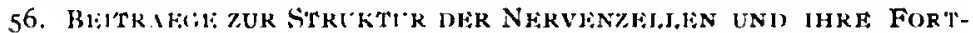
SA 1: T\%1:(Combributions 10 the Structure of the Nerve Cell). Hans Held 1. Arch. i. Amat. I. Physiologie, Anatomische Abtheilung, No. 2, t697, p). 3. 4 '.

This is one of the most inuportant contributions to the finer histolugy of the nerve cell that has thus far appeared.

Thic author first take's np the question of the significance of what have been termed the "chromoplylic" granules. Held has already claimed that these granules, described more particularly by Nissl, were arte-ficts due to the fixative solutions used, and in his previous contribution in the same jourual. I 89.5 . gave a number of experimental proofs to support his assortiult. The present communication is an answer to Lenlossek's criticism of his earlier paper, wherein Lenhossek st: tes that the grantules liave been observed by him in the fresh specintens. The author adopts the idea that the Nissl granules are brouglit out by means of acirl fixatives, and shows that in spinal cord fixed with weik alkaline solutions is to to per cent. $\mathrm{NaOH}$ was used) the large colls in the auterior loorus were completely lacking in these chamateristic bodie's, and that when lae fixed with aleolool (which 
1. neariy ahwa:- acid) or alcohol plus a small anount of acid, acetic usually being userl. the granules were very conspicuous. The author further considers the standpoint of physiological chemistry, which teaches that the reaction of living nervous tissue is alkaline. but that alnust immeoliately after death the reaction becones acid. sometimes uithin a jew minutes. This development of acill is. in the anthor's mind. the cause of the formation of the Nissl chromopleylic bodies.

The piper further considers the erudite questions of the structure wi protoplasus. the nerve cells in particular being the ground debated upwin. Held is inclined to adopt the reticulum theory. somewhat menlited from the original leromam point of view. ancl rejects the filat theor: of Fleming. The article is one that camot be omitted frum the ange of the neurologist's reading if he is interested in the porbiens of structure and the interpretation uf microscopical pittures.

JELIJIFEE.

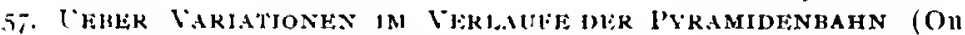
Variations in the Course of the Pyramialal Tract). A. Hoche (Neumlor. Centralblatt. 16, 184)7. No, 21).

The author contributes to this subicet the anatomical findings in a case of glio-sarcomia, situated in the central courolutions, causing desccuriang degencration. in the pyramilal tract; the contse of the latter was foumel to viry irom thit usually olsserved. Foxamination by Marchi: methoil showed that iu the perduncle, pous and medulla the reginn of the left pyramid was exelusively degeneraterl.

"lhe decussation oceurred at the normal level. but a portion of the fibre- pasedel down into the opposite anterior tract.

Thi- lecussated anterior tract extended throughout the entire ievical renion of the cord, and disappeared at the level of the first rorsil root.

Amother nunsual occurrence was the extension forward of the area of degeneration beyoud the ordimary region of the lateral pyramidal tract. Which normally does not reach beyond a line drawn through the lateral horns.

It the ll. ecrrical in Gower's tract a bundle was observed. which showed itseli throughout the cervical cord as an irregular figure.

Throughout the dorsal eord the crossed pyramidal tract extended aiser) too far forwarkl. and even in the lumbar region the pyrantidal area was greater than usilat.

The direct pyramidal tract showed a hook-like formation as low drum as the rlorsal region.

.11:1k011:17\%.

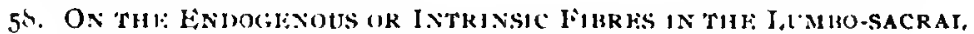

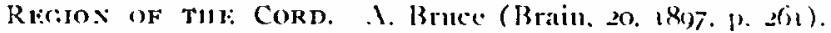

The author discusses the fibres found in the posterior columns of thi. cord in the lunbo-sacral region, termed by Marie the endogennus fibres. These fibres form two very well-marked tricts. one lying in the anterion part of the posterior columm, in close apposition to the ponterior cornu, commissure and septum: the secont in inmediate relationship in the posterior median septum, and in part to the posterior suriace of the cord. The first tract, the cormu-commissural tract (Hinterstrangsield): the second. termed by the author the scpto-marginal trat. "Edinger's medianische's Ilinterstrangsfeld."

These fibres do not degenerate upward according to the author. being spared in locomotor ataxia; but they do suffer degeneration in cullelitions which induce degeneration in the cells of the posterior liurns.

1.) The cormu-commissural tract extends through the whole of the lumbu-sacral region. heing traceable from the lowest dorsal segments 